\title{
Core Criteria Affecting Decisions to Select Logistics Services Suppliers in Hồ Chí Minh City
}

\author{
LÊ TẤN BỬU \\ University of Economics HCMC - buult@ueh.edu.vn
}

TRÀN MINH CHÍNH

Saigon College of Economics and Technology - chinh.minhtran@yahoo.com

ĐẶNG NGUỸ̃̃N TÁT THÀNH

Royal Dragon Import Export Joint Stock Company - thanh.dangnguyentat@gmail.com

\begin{tabular}{|c|c|}
\hline N & BST \\
\hline $\begin{array}{l}\text { ed: } \\
\text { May } \\
\text { ed in } \\
\text { July } \\
\text { ted: } \\
\text { Sep }\end{array}$ & \multirow{2}{*}{$\begin{array}{l}\text { Outsourcing of logistics services has become popular since the } \\
\text { beginning of the } 21^{\text {st }} \text { century. Along with increasingly great changes } \\
\text { in supply of logistics services, exploring customers' demand and } \\
\text { core criteria affecting decisions to select logistics services suppliers } \\
\text { becomes increasingly necessary. Employing the EFA and binary } \\
\text { logistic regression, the research identifies eight core criteria affecting } \\
\text { decisions to select service suppliers by HCMC-based exporters and } \\
\text { importers: quick response to customers' demand, updating service } \\
\text { supplying fares, brand reputation of logistics services suppliers; } \\
\text { exact billing; care of customers' interests and needs; location of } \\
\text { service suppliers; availability of e-commerce services and electronic } \\
\text { billing; and reasonable pricing. }\end{array}$} \\
\hline & \\
\hline
\end{tabular}




\section{INTRODUCTION}

VN currently has over 1,200 logistics services suppliers, categorized into three groups: multinationals, joint-ventures with foreign partners and local enterprises (stateowned and private ones).

Multinational enterprises characterized by diverse services, financial strength, and powerful systems of tangible and qualified managerial skills act as third-party logistics (3PLs) and take the biggest market share. Besides a few large-sized and well-funded SOEs acting as 3PLs; most local enterprises are second-party logistics (2PLs) providers because they can only supply retail services in logistics chain. Up to $80 \%$ of local enterprises supply logistics services of levels 1 and 2, whereas a few remaining ones are $3^{\text {rd }}$ and $4^{\text {th }}$-level service suppliers. Even a small number of SOEs that established joint stock companies after equitization have only around VND5 billion as their chartered capital (Song Hà, 2013).

Thus, most local enterprises are only capable of providing and exploiting very small sections in the entire chain of value-added logistics services. Although some local enterprises, such as Viettrans, Viconship, and Vinatrans, have developed their size and gained good experience, they could not engage in global operations. This is considered one drawback of logistics enterprises since the field is typical for its closed process, requiring an integration of multiple services which can be carried out in various countries (Cao, 2013).

Globalization has led to an increase in trading for many countries, especially Vietnam. Logistics activities play a crucial role in supporting import-export businesses. To improve efficiency and competitiveness, importers/exporters should perform professional specialization that enhances their core values. Outsourcing of logistics services allows them to take advantage of the network, experience and expertise of logistics enterprises to enhance competitiveness and expand the market. The study aims at identifying the factors and core criteria that affect decisions to select logistics services suppliers. Its results may help logistics enterprises form a panoramic view over their market segments, help 2PLs restructure and develop into 3PLs and help 3PLs build appropriate business and marketing strategies to retain regular customers and attract new ones and policy makers. 


\section{THEORETICAL BASES AND METHODOLOGY}

As defined by Bottani \& Rizzi (2006), the process of selecting logistics services suppliers consists of five major steps: (1) Identifying the need for logistics outsourcing; (2) Assessing feasible alternatives by comparison between self implementation and outsourcing of logistics services; (3) Evaluating the candidates and selecting appropriate suppliers; (4) Conducting the services; and (5) Assessing the services after each use to control the implementation and making decisions on new suppliers and/or reinforcing the coordination between goods owners and current logistics suppliers. These steps, despite their apparent discrepancies, are closely connected and do not necessarily comply with an imposed order. Service quality provided by a certain logistics enterprise has a thorough influence on the selection of logistics services suppliers. Steps 2 and 5 in Bottani \& Rizzi (2006)'s study are related to the available service quality. In case of poor-quality services, the owners would carry out logistics services on their own and directly contact with carriers or airlines that offer transportation of import-export goods.

Studies by Banomyong \& Supatn (2011), Faris et al. (1967), Bottani \& Rizzi (2006), Spencer et al. (1994), and Wilding \& Juriado (2004) assume that decisions to select logistics services suppliers are dependent on two main factors: service costs and quality (including both prestige and brand name). Results from a 2008 survey by the Research and Consulting Department of Bien Hoa SCM Co., Ltd. draw a valid conclusion: Service costs and quality are always the prerequisites upon the signing of service contracts.

This study employs both qualitative and quantitative methods. First, qualitative research features face-to-face interviews with 10 respondents (five from logistics services companies and five from import-export enterprises) and a trial survey with eight import-export officers. Next, quantitative research is implemented through a questionnaire applying 5-point Likert scale.

Importers/exporters in HCMC in four leading industries, footwear, textile, electronics - computer, and chemicals are selected as subject of survey. Convenience sampling method is applied. However, to highlight representativeness, 400 questionnaires are evenly distributed among four industries (100 questionnaires each) according to convenience sampling process. Of returned questionnaires, 227 valid ones are encoded and analyzed by means of SPSS 20.0. 
Scales for constructs are tested by Cronbach's Alpha and Explanatory Factor Analysis (EFA), and binary logistic regression model is used for testing hypotheses and overall fitness of the model, which is statistically significant when the sig. (pvalue) of Chi-square test is less than a significance level (often at 5\%). The higher the fitness, the less the coefficient $-2 \log$ likelihood (-2LL) and the more accurate the estimation rates reveal.

Equation 1: a linear regression model with non-linear relationships that describes the factors' impact on decisions to select logistics services suppliers is developed as follows:

$$
\log _{e}[P(Y=1) / P(Y=0)]=B_{0}+B_{1} * X 1+B_{2} * X_{2}+\ldots+B_{k} * X_{k}
$$

where:

$\mathrm{Y}$ : the binary dependent variable $(\mathrm{Y}=1$ : selection of logistics services suppliers or concurrent vessel or plane charter and outsourcing of logistics services; and $\mathrm{Y}=0$ : self implementation of logistics activities and vessel or plane chartered only for transportation of imports/exports)

$\mathrm{B}_{0}$ : the random error of overall regression function

$\mathrm{B}_{\mathrm{k}}$ : the partial regression coefficient $(\mathrm{k}=1 \ldots \mathrm{n})$

$\mathrm{X}_{\mathrm{i}}$ : the independent variable

Table 1. Independent Variables and Expectations

\begin{tabular}{llc}
\hline Variable & Code & Expected sign \\
\hline Responsiveness & DU & + \\
Assurance & DB & + \\
Reliability & TC & + \\
Empathy & DC & + \\
Service costs & GC & + \\
Tangibility & HH & + \\
\hline
\end{tabular}

\section{RESEARCH MODEL AND HYPOTHESES}

Based on the SERVQUAL model proposed by Valarie et al. (1985), Parasuraman et al. (1988) and other relevant studies, the study on criteria for selecting one 3PL by Banomyong \& Supatn (2011) puts forward six of the following primary components: (1) reliability, (2) assurance, (3) responsiveness, (4) tangibles, (5) empathy, and (6) 
service costs, all of which affect decisions to select one 3PL. The results of the study, empirically conducted in Thailand with a sample of 167 respondents, demonstrate that only four of the components, namely (1) reliability, (2) assurance, (3) responsiveness, and (4) service costs do exert effects on decisions. The other two components tangibles and empathy - despite their statistical insignificance still reveal certain effects.

Parasuraman et al. (1988) establish a SERVQUAL model with five components to evaluate the service quality: (1) reliability, (2) assurance, (3) tangibles, (4) empathy, and (5) responsiveness. Service costs may also be used to determine essential factors affecting decisions to select logistics services suppliers (Bienstock et al., 1997).

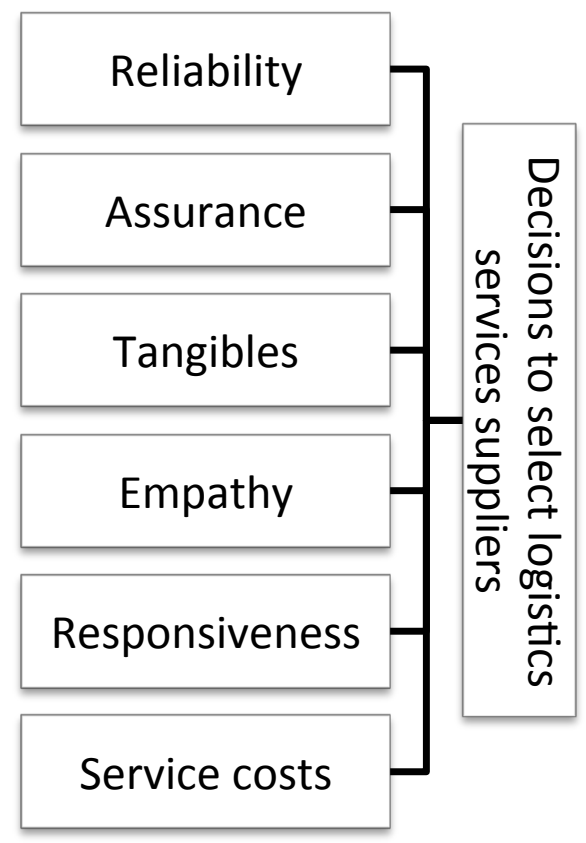

Figure 1. Proposed Research Model

Figure 1 illustrates the six components introduced to the study's model, adapted from researches by Valarie et al. (1985), Parasuraman et al. (1988), Bienstock et al. (1997), Wilding \& Juriado (2004), and Banomyong \& Supatn (2011). In respondents' perspective revealed during face-to-face interviews, service costs should be well substituted with pricing. Since the concepts, in fact, treat this component as a sort of 
payment methods, discount offers or easy payment, 'pricing' would be a more suitable label.

Reliability: The reliability is signaled by the adequate service supply and binding commitments to importers/exporters (Parasuraman et al., 1988). Accuracy in document preparations, consistent service performance along lower transit times should be the shippers' expectations for the service quality offered by logistics enterprises and obviously, it does affect decisions on logistics services suppliers (Banomyong \& Supatn, 2011).

Assurance: Staff qualifications as well as brand name of logistics services suppliers generate goods owners' trust and confidence, which is another provider selecting criterion. Brand reputations of logistics enterprises are viewed as an assurance about timely delivery, minimization of goods damaged in transit and uniformity over the entire system. Customer trust is built upon the basis of knowledge, experience along the staff's manner of dealing with goods owners (Parasuraman et al., 1988; Banomyong \& Supatn, 2011).

Tangibles: These serve as means of supplying services and establishing position of logistics enterprises (Parasuraman et al., 1988; Banomyong \& Supatn, 2011). The trend of e-commerce and use of electronic documents in logistics services are growing increasingly popular. Swift progress of information technology has enabled logistics enterprises to conveniently gather process and exchange information in the transportation of goods and documents. Yet, in the context of Vietnam where ecommerce and electronic documents have yet to be perceived as comprehensively developed and widely accepted by public authorities, the positions of logistics enterprises prove a criterion affecting decisions to select appropriate suppliers due to convenience in trading with electronic documents, as compared to paper ones.

According to Rafele (2004), tangibles are available means and resource to provide a service, compliant with tangibles suggested in the SERVQUAL model by Parasuraman et al. (1988). Rafele (2004) and Banomyong \& Supatn (2011) highlight the important role of tangibles in the selections of suppliers.

Empathy: This expresses attention and care for each individual customer, and it is the human factor itself that is vital to the success (Parasuraman et al., 1998). Having their interests and needs looked after, information kept safe and a long-lasting cooperation with logistics enterprises established are aspects all importers/exporters care 
about and they would directly affect the selection of logistics providers (Banomyong \& Supatn, 2011). Importers/exporters want to have their problems quickly handled by logistics enterprises. If service providers offer a sound customer relationship system, importers/exporters should highly appreciate their services, which could also become a top standard for selecting the providers because the customer relationship system not simply supports the management of customer base but improves the relationship between the staff and customers and well manage customers' information to provide them with better services.

Responsiveness: This component refers to a readiness and/or willingness of employees to provide timely services (Parasuraman et al., 1988). Prompt responses to customers' demand are all-time great expectations. Staff enthusiasm and instant responsiveness are keynote factors that decide consumer loyalty and support word-ofmouth marketing, an effective strategy at the present time. Service charges constantly updated are also under importers/exporters' consideration as this becomes a basis for estimating costs and profit of each shipment (Banomyong \& Supatn, 2011).

Pricing: Regarded as an overriding concern, pricing is seen as an initial factor relating to logistics enterprises perceived by customers. This is also essential to influence consumer's satisfaction and decisions to use the service provided and select logistics services suppliers (Bienstock et al., 1997; Wilding \& Juriado, 2004; Banomuong \& Supatn, 2011). The more competitive and reasonable logistics services pricing is assessed as, the greater it affects the selection decisions. Furthermore, according to Banomyong \& Supatn (2011), logical payment methods and high discount rates will result in more effects on such decisions.

\section{RESEARCH RESULTS}

\subsection{Measure}

Scales of the factors affecting decisions to select logistics service suppliers consist of six components: (1) reliability; (2) assurance; (3) tangibles; (4) empathy; (5) responsiveness; and (6) pricing that comprise 29 observed variables as illustrated in Table 2. 
Table 2. Encoding the Scales

\begin{tabular}{cll}
\hline Order & Code & \\
\hline Reliability & & \\
1 & TC1 & Accurate documents \\
2 & TC2 & Short transfer time \\
3 & TC3 & Consistence of the services \\
4 & TC4 & No errors found \\
\hline
\end{tabular}

\begin{tabular}{cll}
\hline $\begin{array}{c}\text { Assurance } \\
1\end{array}$ & DB1 & Brand reputation of logistics services suppliers \\
2 & DB2 & Supply of track-and-trace service \\
3 & DB3 & No damage in transit \\
4 & DB4 & Knowledge and experience of logistics service staff \\
5 & DB5 & Supply of full package services \\
6 & DB6 & Rousing, courteous serving styles of logistics services staff \\
\hline Tangibles & & \\
1 & HH1 & Locations of logistics enterprises \\
2 & HH2 & Modern equipment \\
3 & HH3 & Supply of e-commerce and e-document services \\
4 & HH4 & Availability of procurement stations \\
\hline Empathy & & \\
1 & DC1 & Confidentiality of information \\
2 & DC2 & Care of customers' interests and needs \\
3 & DC3 & Maintenance of good customer relationship \\
\hline
\end{tabular}

\section{Responsiveness}

$\begin{array}{lll}1 & \text { DU1 } & \text { Prompt response to customers' demand } \\ 2 & \text { DU2 } & \text { Global supply network } \\ 3 & \text { DU3 } & \text { Updating service charges } \\ 4 & \text { DU4 } & \text { Excellent customer service } \\ 5 & \text { DU5 } & \text { Availability of overseas service network } \\ 6 & \text { DU6 } & \text { Diversification of services }\end{array}$




\begin{tabular}{cll}
7 & DU7 & $\begin{array}{l}\text { Supply of courier services } \\
\text { Level of staff readiness }\end{array}$ \\
\hline Pricing & DU8 & \\
1 & GC1 & Reasonable pricing \\
2 & GC2 & Easy payment \\
3 & GC3 & Appropriate payment methods \\
4 & GC4 & Discount offers \\
\hline
\end{tabular}

\subsection{Sample Description}

Respondents by industry: 60 (26.4\%) of them are in chemical industry, $58(25.6 \%)$ in textile industry, $55(24.2 \%)$ in footwear industry and $54(23.8 \%)$ in electricalelectronics industry. The proportions between the industries are comparable.

Concerning their fields of activities: 66 (29.0\%) of them engage in export business, $73(32.2 \%)$ in import and 88 in both. Most of them have to import raw materials for manufacturing exports; thus, the proportions are well suited.

Regarding modes of transport: 170 (74.9\%) of respondents chiefly have their goods transported by sea, 20 (8.8\%) prefer air transport and $37(16.3 \%)$ employ both modes. Since most imports and exports in Vietnam are usually transported by ship, it is reasonable that its proportion dominates.

Concerning outsourcing practice: 84 respondents $(37.0 \%)$ outsource shipping services (by ships or planes); 83 (36.6\%) outsource logistics services and 60 (26.4\%) employ both means. Outsourcing of logistics services in Vietnam has yet to be a common case because exporters and importers usually implement their tasks on their own and only outsource transport work.

\section{Table 3. Information of Samples}

\begin{tabular}{llcc}
\hline & Characteristics of Sample $(\mathbf{n}=\mathbf{2 2 7})$ & Quantity & Percentage (\%) \\
\hline Industry & Chemical & 60 & 26.4 \\
& Textile & 58 & 25.6 \\
& Footwear & 55 & 24.2 \\
Electrical - electronics & 54 & 23.8 \\
& & & \\
\hline
\end{tabular}




\begin{tabular}{llcc}
\hline Field of & Only export & 66 & 29.0 \\
activity & Only import & 73 & 32.2 \\
& Both export and import & 88 & 38.8 \\
\hline Modes of & Mainly sea transport & 170 & 74.9 \\
transport & Mainly air transport & 20 & 8.8 \\
& Both sea and air transport & 37 & 16.3 \\
\hline Outsourcing & Outsourcing of only shipping services & 84 & 37.0 \\
practice & Outsourcing of only logistics services & 83 & 36.6 \\
& Outsourcing of both shipping and logistics & 60 & 26.4 \\
& services & & \\
\hline
\end{tabular}

\subsection{Tests of Scales}

Scales of the components affecting decisions to select logistics services suppliers include: (1) reliability; (2) assurance; (3) tangibles; (4) empathy; (5) responsiveness; and (6) pricing that comprises 29 observed variables tested by Cronbach's Alpha. The results demonstrate that 27 components are included in EFA process while the other two variables DU2 and GC2 are eliminated due to item-total correlation less than 0.3.

Table 4. Cronbach's Alpha Test

\begin{tabular}{lcccc}
\hline \multicolumn{1}{c}{ Scale } & $\begin{array}{c}\text { Number } \\
\text { of items }\end{array}$ & $\begin{array}{c}\text { Cronbach's } \\
\text { Alpha }\end{array}$ & $\begin{array}{c}\text { Cronbach's } \\
\text { Alpha } \\
\text { If Item Deleted }\end{array}$ & Note \\
\hline Reliability & 4 & 0.809 & 0.809 & \\
Assurance & 6 & 0.876 & 0.876 & \\
Tangibles & 4 & 0.810 & 0.810 & \\
Empathy & 3 & 0.883 & 0.883 & DU2 deleted \\
Responsiveness & 8 & 0.894 & 0.919 & GC2 deleted \\
Pricing & 4 & 0.734 & 0.849 & \\
\hline
\end{tabular}

The EFA is performed through the Principle Components Analysis (PCA) and varimax rotation. In the first analysis, TC4 is eliminated since its factor loading equals $0.457(<0.5)$. In the second analysis, the items DU8, HH4, DB6 and DB2 are eliminated because their factor loadings are lower than 0.3 (Table 5 ). 
Table 5. Second Rotation Matrix

\begin{tabular}{|c|c|c|c|c|c|c|}
\hline \multirow{2}{*}{ Item } & \multicolumn{6}{|c|}{ Factor } \\
\hline & 1 & 2 & 3 & 4 & 5 & 6 \\
\hline DU6 & 0.844 & 0.080 & 0.012 & 0.020 & 0.224 & -0.006 \\
\hline DU3 & 0.843 & 0.113 & 0.039 & 0.038 & 0.213 & 0.052 \\
\hline DU7 & 0.809 & 0.259 & 0.083 & 0.139 & 0.094 & 0.103 \\
\hline DU4 & 0.801 & 0.143 & 0.127 & 0.129 & 0.166 & 0.100 \\
\hline DU5 & 0.783 & 0.199 & 0.091 & 0.130 & 0.131 & 0.146 \\
\hline DU1 & 0.761 & 0.222 & 0.158 & 0.214 & 0.148 & 0.178 \\
\hline DB5 & 0.100 & 0.824 & 0.035 & 0.238 & 0.100 & 0.215 \\
\hline DB4 & 0.227 & 0.794 & 0.155 & 0.146 & 0.128 & 0.159 \\
\hline DB3 & 0.210 & 0.729 & 0.160 & 0.056 & 0.196 & 0.143 \\
\hline DB1 & 0.100 & 0.674 & 0.197 & 0.355 & 0.146 & 0.107 \\
\hline DU8 & 0.445 & 0.631 & 0.058 & 0.106 & 0.060 & 0.173 \\
\hline HH4 & 0.225 & 0.563 & -0.043 & 0.033 & 0.497 & 0.065 \\
\hline DB6 & 0.150 & 0.531 & 0.020 & 0.241 & 0.424 & 0.181 \\
\hline $\mathrm{TC} 1$ & 0.119 & 0.056 & 0.898 & 0.155 & 0.087 & 0.082 \\
\hline TC3 & 0.070 & 0.100 & 0.872 & 0.189 & 0.068 & 0.096 \\
\hline $\mathrm{TC} 2$ & 0.087 & 0.067 & 0.828 & 0.043 & 0.190 & 0.129 \\
\hline$D B 2$ & 0.128 & 0.521 & 0.644 & -0.001 & -0.073 & -0.007 \\
\hline DC3 & 0.155 & 0.146 & 0.111 & 0.878 & 0.149 & 0.107 \\
\hline $\mathrm{DC} 2$ & 0.215 & 0.217 & 0.202 & 0.788 & 0.140 & 0.138 \\
\hline $\mathrm{DC} 1$ & 0.117 & 0.277 & 0.099 & 0.781 & 0.121 & 0.201 \\
\hline HH2 & 0.215 & 0.195 & 0.111 & 0.107 & 0.832 & 0.038 \\
\hline HH3 & 0.289 & 0.058 & 0.209 & 0.148 & 0.715 & 0.082 \\
\hline HH1 & 0.253 & 0.247 & 0.052 & 0.142 & 0.700 & 0.141 \\
\hline $\mathrm{GC} 3$ & 0.102 & 0.207 & 0.126 & 0.011 & 0.171 & 0.829 \\
\hline $\mathrm{GC} 1$ & 0.126 & 0.193 & 0.107 & 0.190 & 0.135 & 0.826 \\
\hline $\mathrm{GC} 4$ & 0.170 & 0.179 & 0.073 & 0.236 & -0.033 & 0.805 \\
\hline
\end{tabular}


The results of the factor analysis indicate that six components remain intact, comprising (1) reliability; (2) assurance; (3) tangibles; (4) empathy; (5) responsiveness; and (6) pricing. All of them affect decisions to select logistics services suppliers; however, the number of variables falls from 27 to 22 .

Table 6. EFA Results

\begin{tabular}{lccc}
\hline \multicolumn{1}{c}{ Interpretation } & First Analysis & Second Analysis & Third Analysis \\
\hline Number of items & 27 & 26 & 22 \\
KMO and Bartlett's & $\begin{array}{c}\text { KMO }=0.851 \\
\text { Sig. }=0.000\end{array}$ & KMO $=0.852$ & KMO $=0.860$ \\
Sig. $=0.000$ & Sig. $=0.000$ \\
Eigenvalues & $=1.400$ & $=1.354$ & $=1.226$ \\
$\begin{array}{l}\text { Total variance } \\
\text { explained }\end{array}$ & $=72.313$ & $=74.245$ & $=77.855$ \\
$\begin{array}{l}\text { Number of factors } \\
\text { extracted }\end{array}$ & 6 & 6 & 6 \\
$\begin{array}{l}\text { Deleted item } \\
\text { Cause }\end{array}$ & TC4 & DU8, HH4, DB6, DB2 & Acceptable \\
\hline
\end{tabular}

Finally, Table 6 show that 6 factors are extracted from 22 observed variables. Grouping of these factors' items is as follows:

- The first factor includes items DU1, DU3, DU4, DU5, DU6, and DU7, grouped into DU (responsiveness);

- The second factor includes items DB1, DB3, DB4, and DB5, grouped into DB (assurance);

- The third factor includes items TC1, TC2, and TC3, grouped into TC (reliability);

- The fourth factor includes items DC1, DC2, and DC3, grouped into DC (empathy);

- The fifth factor includes items GC1, GC3, and GC4, grouped into GC (pricing); and

- The sixth factor includes items $\mathrm{HH} 1, \mathrm{HH} 2$, and $\mathrm{HH} 3$, grouped into $\mathrm{HH}$ (tangibles). 
To examine whether the new labelled items DU, DB, TC, DC, GC and HH have effects on decisions to select logistics services suppliers, the next section will employ the Binary Logistics Regression Analysis.

\subsection{Binary Logistic Regression Analysis}

The results of the binary logistics regression analysis using Enter method demonstrate that all of the six components positively affect decisions to select logistics services providers made by HCM-based importers/exporters. In particular, the most powerful impact on the selection decisions is exerted by responsiveness (reg. coef. $=$ 1.955), followed by pricing (reg. coef. $=1.767$ ), tangibles (reg. coef. $=1.621$ ), assurance (reg. coef. $=1.393)$, reliability (reg. coef. $=0.918)$ and finally, empathy (reg. coef. $=0.869)$.

The results in Table 7 signify the $p$-value less than the sig. level $\alpha=0.05$, revealed by selection decisions; thus, hypothesis $\mathrm{H}_{0}$ can be rejected; regression coefficients having been explored are statistically significant and the model is appropriate.

Table 7. Results of Regression Analysis

\begin{tabular}{cccccccc}
\hline & & B & S.E. & Wald & Df & Sig. & Exp(B) \\
\hline \multirow{4}{*}{ Step 1 $^{\text {a }}$} & DU & 1.955 & 0.655 & 8.907 & 1 & 0.003 & 7.063 \\
& DB & 1.393 & 0.445 & 9.808 & 1 & 0.002 & 4.027 \\
& TC & 0.918 & 0.410 & 5.005 & 1 & 0.025 & 2.505 \\
& DC & 0.869 & 0.366 & 5.630 & 1 & 0.018 & 2.384 \\
& GC & 1.767 & 0.417 & 17.941 & 1 & 0.000 & 5.851 \\
& HH & 1.621 & 0.631 & 6.589 & 1 & 0.010 & 5.056 \\
& Constant & -30.751 & 40.639 & 43.939 & 1 & 0.000 & 0.000 \\
\hline
\end{tabular}

Chi-square: Sig. $=0.000$

$-2 \mathrm{LL}=91.307$

Probability of correct forecast: $93.4 \%$

Based on the results from Table 7, the Binary Logistic Regression Equation is re written as:

$\log _{e}[P(Y=1) / P(Y=0)]=-30.751+1.955 *$ Responsiveness $+1.393 *$ Assurance + $0.918 *$ Reliability $+0.869 *$ Empathy $+1.767 *$ Pricing $+1.621 *$ Tangibles 
The marginal effect of responsiveness on decisions to select logistics services suppliers (original prob. $=0.5$ ) is $0.5(1-0.5) 1.955=0.4888$. The marginal effects of assurance, reliability, empathy, pricing and tangibles are $0.3483 ; 0.2295 ; 0.2173$; 0.4418 ; and 0.4053 respectability. Accordingly, it can be concluded that an increase in the value of any component out of the six suggested ones results in higher selection decisions.

Each of the components affecting decisions to select logistics services suppliers has several criteria (observed variables measuring that component). Six Binary Logistics Regression Analyses are performed among the observed variables with the dependent variable being the selection decisions. After that, core criteria of each component will be identified.

Responsiveness: The highest-impacting item is DU1 $(\mathrm{B}=2.323 \&$ sig. $=1 \%)$, followed by DU3 $(\mathrm{B}=1.471 \& \mathrm{sig} .=5 \%)$. Accordingly, the two core criteria of responsiveness are DU1 - prompt response to customers' demand and DU3 - updating service charges (Table 8).

Table 8. Results of Regression Analysis

\begin{tabular}{|c|c|c|c|c|c|c|c|}
\hline & & B & S.E. & Wald & df & Sig. & $\operatorname{Exp}(B)$ \\
\hline \multirow{7}{*}{ Step $1^{\mathrm{a}}$} & DU1 & 2.323 & 0.678 & 11.751 & 1 & 0.001 & 10.211 \\
\hline & DU3 & 1.471 & 0.712 & 4.264 & 1 & 0.039 & 4.353 \\
\hline & DU4 & 1.287 & 0.532 & 5.842 & 1 & 0.016 & 3.621 \\
\hline & DU5 & 0.973 & 0.559 & 3.027 & 1 & 0.082 & 2.645 \\
\hline & DU6 & -1.771 & 0.741 & 5.720 & 1 & 0.017 & 0.170 \\
\hline & DU7 & -1.215 & 0.774 & 2.467 & 1 & 0.116 & 0.297 \\
\hline & Constant & -10.825 & 1.547 & 48.956 & 1 & 0.000 & 0.000 \\
\hline
\end{tabular}

Assurance: The highest-impacting item is DB1 $(\mathrm{B}=0.885 \&$ sig. $=1 \%)$; therefore, the core criterion of assurance is DB1 - brand reputation of logistics services enterprises (Table 9). 
Table 9. Results of Regression Analysis

\begin{tabular}{cccccccc}
\hline & & B & S.E. & Wald & df & Sig. & $\operatorname{Exp(B)}$ \\
\hline & DB1 & 0.885 & 0.281 & 9.889 & 1 & 0.002 & 2.422 \\
Step 1 $^{\mathrm{a}}$ & DB3 & 0.583 & 0.247 & 5.595 & 1 & 0.018 & 1.792 \\
& DB4 & 0.636 & 0.317 & 4.019 & 1 & 0.045 & 1.888 \\
& DB5 & 0.214 & 0.270 & 0.626 & 1 & 0.429 & 1.238 \\
& Constant & -8.158 & 1.188 & 47.119 & 1 & 0.000 & 0.000 \\
\hline
\end{tabular}

Reliability: The highest-impacting item or the only one with sig. $=5 \%$ is $\mathrm{TC} 1-$ accurate documents $(\mathrm{B}=0.743)$, which is accordingly regarded as the core criterion of reliability (Table 10).

Table 10. Results of Regression Analysis

\begin{tabular}{|c|c|c|c|c|c|c|c|}
\hline & & B & S.E. & Wald & df & Sig. & $\operatorname{Exp}(B)$ \\
\hline \multirow{4}{*}{ Step $1^{\mathrm{a}}$} & $\mathrm{TC} 1$ & 0.743 & 0.370 & 4.024 & 1 & 0.045 & 2.102 \\
\hline & TC2 & 0.417 & 0.273 & 2.325 & 1 & 0.127 & 1.517 \\
\hline & TC3 & 0.023 & 0.348 & 0.004 & 1 & 0.948 & 1.023 \\
\hline & Constant & -3.738 & 0.808 & 2.430 & 1 & 0.000 & 0.024 \\
\hline
\end{tabular}

Empathy: The highest-impacting item is DC2 - care of customers' interests and demand $(\mathrm{B}=1.030 \&$ sig. $=1 \%)$, thereby being deemed the core criterion of empathy (Table 11).

Table 11. Results of Regression Analysis

\begin{tabular}{|c|c|c|c|c|c|c|c|}
\hline & & B & S.E. & Wald & df & Sig. & $\operatorname{Exp}(B)$ \\
\hline \multirow{4}{*}{ Step $1^{\mathrm{a}}$} & DC1 & 0.875 & 0.251 & 12.113 & 1 & 0.001 & 2.399 \\
\hline & DC2 & 1.030 & 0.284 & 13.183 & 1 & 0.000 & 2.802 \\
\hline & DC3 & 0.038 & 0.254 & 0.023 & 1 & 0.880 & 1.039 \\
\hline & Constant & -6.147 & 0.913 & 45.322 & 1 & 0.000 & 0.002 \\
\hline
\end{tabular}


Tangibles: The highest-impacting item is $\mathrm{HH} 1(\mathrm{~B}=1.822 \&$ sig. $=1 \%)-$ locations of logistics enterprises, which is considered the core criterion of tangibles, and next comes HH3 - supply of e-commerce and e-document services (Table 12).

Table 12. Results of Regression Analysis

\begin{tabular}{cccccccc}
\hline & & B & S.E. & Wald & df & Sig. & $\operatorname{Exp(B)}$ \\
\hline & HH1 & 1.822 & 0.367 & 24.657 & 1 & 0.000 & 6.185 \\
Step 1 $^{\text {a }}$ & HH2 & 0.303 & 0.356 & 0.725 & 1 & 0.394 & 1.354 \\
& HH3 & 0.876 & 0.336 & 6.796 & 1 & 0.009 & 2.401 \\
& Constant & -10.552 & 1.484 & 50.541 & 1 & 0.000 & 0.000 \\
\hline
\end{tabular}

Pricing: The highest-impacting item is $\mathrm{GC} 1$ - reasonable pricing $(\mathrm{B}=1.118$ \& sig. $=1 \%$ ), being also the core criterion of pricing (Table 13).

Table 13. Results of Regression Analysis

\begin{tabular}{cccccccc}
\hline & & B & S.E. & Wald & df & Sig. & $\operatorname{Exp(B)}$ \\
\hline \multirow{3}{*}{ Step 1 } & GC1 & 1.118 & 0.289 & 14.998 & 1 & 0.000 & 3.059 \\
& GC3 & 0.344 & 0.222 & 2.411 & 1 & 0.120 & 1.411 \\
& GC4 & 0.574 & 0.254 & 5.102 & 1 & 0.024 & 1.775 \\
& Constant & -7.380 & 1.054 & 49.021 & 1 & 0.000 & 0.001 \\
\hline
\end{tabular}

\section{CONCLUSIONS AND POLICY RECOMMENDATION FOR HCMC-BASED LOGISTICS ENTERPRICES}

The results allow the authors to offer six recommendations with emphasis on eight core criteria: (1) prompt response to customers' demand; (2) updating service charges; (3) brand reputation of logistics services enterprises; (4) accurate documents; (5) care of customers' interests and demand; (6) locations of logistics enterprises; (7) supply of e-commerce and e-document services; and (8) reasonable pricing because these factors do affect customers' decisions on selection of the logistics services suppliers.

Responsiveness: A prompt response to customers' demand is always expected by customers. Staff enthusiasm, as well as their quick adaptation to requirements, is important to formation of consumer loyalty and word-of-mouth marketing, a type of marketing strategies in today's context. Additionally, constantly updating service 
charge is another concern because it helps importers/exporters estimate costs and profits of each consignment.

Tangibles: While e-commerce and e-documens have yet to be fully developed and widely accepted by public authorities in Vietnam, location of logistics services suppliers plays an important role in supplier selection process due to its convenience in transactions. Furthermore, supply of e-commerce and e-document services should be of major concern. The rapid progress of information technology itself has helped logistics enterprises gather, process and exchange information with ease and extra convenience during transportation of goods and documents.

Assurance: The brand reputation is closely associated with various aspects of an efficient supply chain, including timely delivery, maximization of damaged goods in transit, prompt return of faulty goods and ensured uniformity over the entire system, especially when importers/exporters apply outsourcing of logistics services to local suppliers based on supplier's strengths. Consumer trust needs be built on staff's knowledge, experience and cooperation with importers/exporters. Another requirement, in addition, is that safety and security for goods should be of top priority and loss or damage of goods should be minimized, except for force majeure.

Reliability: Limiting documentation errors accelerates the procedure of logistic services supply, concurrently building consumer trust and displaying expertise in service supply. Apart from this, logistics enterprises are supposed to enhance supervision and careful examination of the service quality. To achieve this aim, logistics enterprises, in employee's recruitment, should target those with high professionalism and foreign language competence.

Empathy: Importers/exporters always want logistics suppliers help solve arising problems as quickly as possible. Logistics staff should handle each individual customer's case and/or provide guidance in place on integrating electronic data effectively while ensuring privacy practices. Additionally, direct contact with customers would bolster up understanding and timely response to their needs and interest. This can only be manipulated by a sound customer relationship management system, which enables logistics enterprises to systematically and efficiently interact with importers/exporters.

Pricing: Considered the last concern of all aforementioned components, pricing is the importers/exporters' top concern of logistics services and thereby radically affects decisions 
to select logistics services suppliers. Since appropriate discount offers and flexible payment procedures are awaited, these also have positive effects on selection decisions reached by importers/exporters

\section{References}

Banomyong, R. \& N. Supatn (2011), “Selecting Logistics Providers in Thailand: A Shippers' Perspective", European Journal of Marketing, 45(3): 419-437.

Bienstock, C. C., J. T. Mentzer \& M. M. Bird (1997), "Measuring Physical Distribution Service Quality", Journal of the Academy of Marketing Science, 25(1): 31-44.

Bottani, E. \& A. Rizzi (2006), “A Fuzzy TOPSIS Methodology to Support Outsourcing of Logistics Services”, Supply Chain Management: An International Journal, 11(4): 294-308.

Cao Ngọc Thành (2013), "Hạ tầng logistics Việt Nam cần được quan tâm đúng mức", Vietnam Logistics Review, retrieved from http://www.vlr.vn/vn/news/van-ban/van-ban-moi/1632/ha-tanglogistics-viet-nam-can-duoc-quan-tam-dung-muc.vlr.

Faris, C. W., P. J. Robinson \& Y. Wind (1967), Industrial Buying and Creative Marketing, Allyn \& Bacon, Boston.

Parasuraman, A., V. A. Zeithaml \& L. L. Berry (1988), "Servqual: A Multiple-Item Scale For Measuring Consumer Perception of Service Quality", Journal of Retailing, 64: 12-40.

Rafele, C. (2004), "Logistic Service Measurement: A Reference Framework", Journal of Manufacturing Technology Management, 15(3): 280-90.

SCM (2008), "Kết quả khảo sát về logistics của SCM năm 2008: Đánh giá tính hiệu quả sử dụng dịch vụ logistics và $\mathrm{xu}$ hướng tương lai tại Việt Nam”, retrieved from http://www.scmvietnam.com/download/Khao\%20sat\%20logistics\%202008.\%20VN.pdf.

Song Hà (2013), "Doanh nghiệp logistics Việt khó vươn ra thị trường thế giới”, Thời báo Kinh tế Việt Nam, retrieved from http://doanhnhan.vneconomy.vn/20131115081350371P0C5/doanhnghiep-logistics-viet-kho-vuon-ra-thi-truong-the-gioi.htm.

Spencer, M. S., S. R. Dale \& J. D. Patricia (1994), “JIT Systems and External Logistics Suppliers”, International Journal of Operations \& Production Management, 14(6): 60-74.

Valarie, A. Z., A. Parasuraman \& L. L. Berry (1985), "Problems and Strategies in Service Marketing”, Journal of Marketing, 49: 33-46.

Wilding, R. \& R. Juriado (2004), "Customer Perceptions on Logistics Outsourcing in the European Consumer Goods Industry”, International Journal of Physical Distribution \& Logistics Management, 34(8): 628-44. 